\title{
Effects of Climate Change on Vegetation in Desert Steppe Inner Mongolia
}

\author{
Shan Dan, Hejing Li, Liuyan Ping, Xing'en De \\ Water Resources for Pastoral Area of the Ministry of Water Resources, Hohhot, China. \\ Email: shdan9702@yahoo.com.cn
}

Received January $17^{\text {th }}, 2013$; revised June $22^{\text {nd }}, 2013$; accepted July $6^{\text {th }}, 2013$

Copyright (C) 2013 Shan Dan et al. This is an open access article distributed under the Creative Commons Attribution License, which permits unrestricted use, distribution, and reproduction in any medium, provided the original work is properly cited.

\begin{abstract}
As the largest ecosystem in China, Grassland not only provides abundant natural resources for the regional economic development, but also safeguards the environment of north China as it acts as an ecological protective screen. However, because of the arid and semi-arid regions, most grassland are limited by climate seriously, changes in precipitation and temperature can affect the community composition and primary productivity within and through grassland ecosystems. Based on the long period climate data and observational data of vegetation in DAMAOQI grassland Inner Mongolia, the study analyzed the climate change and its effect on community properties by using the linear trend method, etc. The results showed that climate change presented increasing temperature and fluctuant precipitation in the last decades. More precipitation could increase species diversity, and precipitation was better than the temperature for diversity exponents. According to these results, the strategy of soil and water conservation ecological rehabilitation would be provided to respond to the climate change. Increase the vegetation coverage and alleviate soil erosion relying on the selfrestoration capability of natural ecosystems under ecological theories, erect a development system on the balance among the water, the forage and the animal. Transform those traditional extensive methods and enhance family farms vigorously by local conditions, the most important of which is water resource. The strategy of ecological rehabilitation advocates in the soil and water conservation and the ecological construction can be adjusted to the aim that establishes a conservation-minded society and a friendly environment society.
\end{abstract}

Keywords: Diversity; Aboveground Biomass; Dominant Species; Ecological Rehabilitation

\section{Introduction}

With rapid economic development, the world population is growing fast, more and more greenhouse gases have been emitted into the air due to the immoderate and infinite activity of humankind. Increasing levels of greenhouse gases influence the Earth's radiation budget and the Earth's-atmospheric system has had to adjust with the raise of greenhouse gases to keep the energy balance, so the global climate has been irreversibly changed. Lots of results show that temperature will continue to rise and precipitation will increase in China over the next 100 years under the background of global climatic change $[1,2]$.

The area of grassland is about 3.9 million square kilometers in china and grassland type is rich. Inner Mongolian grassland is in the middle of Eurasia, which is a transition zone among the arid region of Northwest and humid region of the North China. It becomes the sensitive zone of global climate change by formidable natural con- ditions, climate fluctuation and complexity of social economy [3]. So studied the technology of soil and water conservation ecological rehabilitation responding to climate change will be improved the quality of regional environments and sustainable development of animal husbandry economy will come true. The research would provide the basis for the response of biodiversity and ecosystem function to temperature increase, and it would be better to carry out ecological rehabilitation work for the soil and water conservation of desert steppe under the climate change.

\section{Materials and Methods}

\subsection{Nature Survey}

Making DAMAOQI grassland in Inner Mongolia as a research object approaches its climate change and the dynamic monitoring of grassland resources. It is the warm temperate zone which is continental monsoon cli- 
mate area, annual mean temperature is $3.5^{\circ} \mathrm{C}$, and annual mean preparation is $284 \mathrm{~mm}$ and chestnut soil. Typical steppe, desert steppe and steppe desert are from south to north on DAMAOQI grassland, azonal vegetation is lower-flat meadow. Desert steppe is largest in zonal vegetations.

\subsection{Methods}

Analyze dynamic changes of meteorological factors, including temperature and precipitation, from 1954 to 2010 in DAMAOQI. Analyze regional land use and grassland productivity based on the TM image and third statistics on grassland resources Inner Mongolia. Calculate diversity exponents: Shannon-Wiener index, Simpson index and Pielou index [4]. Shannon-Wiener index, Simpson index represent the plant species diversity and Pielou index represents the species richness.

$$
\begin{gathered}
\text { Shannon-Wiener index }\left(H^{\prime}\right) \quad H^{\prime}=-\sum p i \cdot \operatorname{Inpi} \\
\text { Simpson index }(D) \quad D=1-\sum p i^{2} \\
\text { Pielou index }(J P) \quad J P=-\frac{\sum p i \ln p i}{\ln s}
\end{gathered}
$$

$S$ is species number, $P i$ is relative coverage, relative density etc. Important Value $(I V)=$ (relative density + relative coverage + relative frequency) $/ 3$.

\section{Results}

\subsection{Annual Variation of Temperature and Annual Variation of Precipitation}

Annual mean temperature is $4.1^{\circ} \mathrm{C}$ in DAMAOQI from 1954 to 2010 , the minimum of mean temperature is $2.1^{\circ} \mathrm{C}$ in 1956 and the maximum is $6.3^{\circ} \mathrm{C}$ in 1998 (Figure 1). Temperature has a clear and fluctuant uptrend during the last 60 years based on the Figure 1. Annual mean temperature of $21 \mathrm{st}$ century is $2.2^{\circ} \mathrm{C}$ higher than fifties on the date variety (Figure 2).

The climate change would cause the distribution of some plant species decreasing, even some plant species vanished, and some plant species distribution space increasing according of several researches [5-7]. Wang Yuhui et al. [8] results suggest that the identification of key elements of temperature change is very important for understanding and predicting the impacts of global warming to grassland communities. So the temperature increase will effect the community composition and structure of grassland and the plant will change to respond the climate warming.

Annual precipitation emerges a great fluctuation from 1954 to 2010 which is not an obvious regularity by using air precipitation information (Figure 3). The maximum precipitation reaches $425.2 \mathrm{~mm}$ in 2003 on record, the

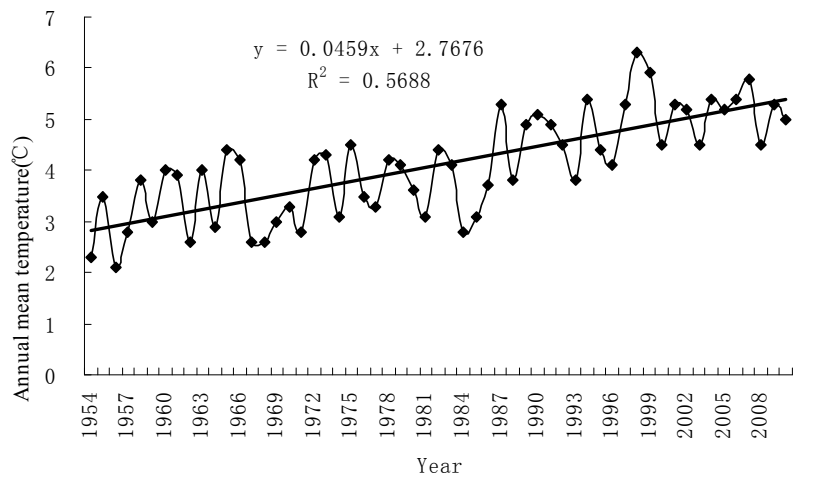

Figure 1. Annual mean temperature variation curve.

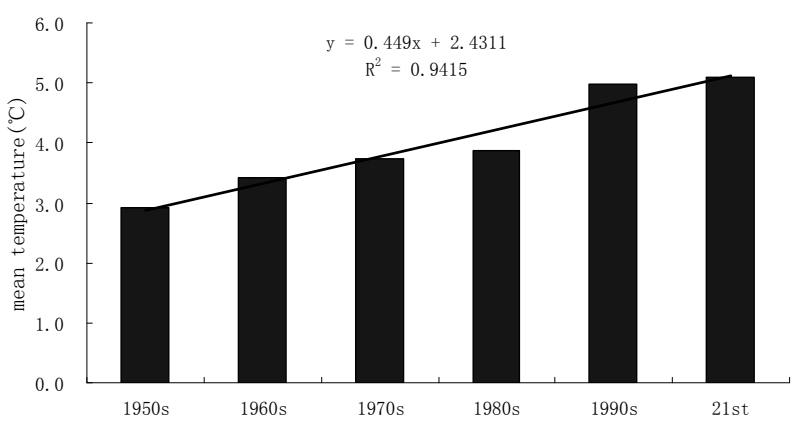

Figure 2. Mean temperature variation of different date.



Figure 3. Annual mean precipitation variation curve.

second best is $400.1 \mathrm{~mm}$ in 1979 and the minimum is $138.4 \mathrm{~mm}$ in 2009 . The mean precipitation is lowest in the sixties and most in seventies (Figure 4).

\subsection{Effect of Climate Change on Plant Species Diversity}

Reserving globe biodiversity has a great value for holding back globe warmer according to the positive feedback causality between the globe warm being warmer and biodiversity $[9,10]$. Changes in plant species diversity were studied in the DMAOQI grassland Inner Mongolia. Based on the correlation analysis, Shannon-Wiener index, Simpson index, Pielou index are positively correlated with precipitation, especially, Shannon-Wiener index is significantly correlated with mean precipitation in 




Figure 4. Mean precipitation variation of different date.

August $(P<0.01)$, which correlation coefficient reaches 0.965. On the other hand, Shannon-Wiener index, Simpson index are negatively correlated with temperature, annual evaporation (Table 1). The results show that the species richness and diversity of the communities rise with an increase precipitation, and with decreasing mean temperature and annual evaporation.

\subsection{Variation of Grassland}

The total grassland is 1551.4 thousand hectare in 2010 by the TM image, which is 85.35 percent in the whole area of DAMAOQI. That utilizing area of grassland is 1396.3 thousand hectare and accounts for 90 percent of the total grassland area (Table 2). Comparative analysis of grassland resources between 2010 and $1980 \mathrm{~S}$, the total area and the utilizing area of grassland has declined 106 thousand hectare and 111.7 thousand hectare respectively for last several decades, which reduce benefits are $6.4 \%$ and $8.0 \%$. Different types of grassland have different changes comparison with 1980 s, the quickest decrease of those types is typical steppe, its total area and utilizing area have reduced about 84.2 and 73.9 thousand hectare respectively, the next is desert steppe, decreasing 22.8 thousand hectare and 34.1 thousand hectare respectively. The area of lower-flat meadow has increased 9.9 thousand hectare that is the main azonal vegetation in DAMAOQI grassland. The land reclamation and use irrationally is the main reasons of grassland degradation, the climate change may accelerate the process.

\section{Conclusion and Discussion}

In this study, the regional temperature rises fluctuated, climate become warming in DAMAOQI Inner Mongolia which is corresponding with global change, annual precipitation varies widely and it is not obvious regularity. The structure and function of the grassland community could be altered if mean temperatures continue to increase. Researching the response of grassland community to climate change not only pays attention to common meteorological factors, such as mean temperature, annual precipitation, but also understands extreme climate fac-
Table 1. Correlation coefficients between diversity and climates.

\begin{tabular}{|c|c|c|c|c|c|}
\hline & $\begin{array}{c}\text { Annual mean } \\
\text { temperature } \\
\left({ }^{\circ} \mathrm{C}\right)\end{array}$ & $\begin{array}{l}\text { Aug mean } \\
\text { temperature } \\
\left({ }^{\circ} \mathrm{C}\right)\end{array}$ & $\begin{array}{l}\text { Annual mean } \\
\text { precipitation } \\
\quad(\mathrm{mm})\end{array}$ & $\begin{array}{l}\text { Aug mean } \\
\text { precipitation } \\
(\mathrm{mm})\end{array}$ & $\begin{array}{c}\text { Annual } \\
\text { evaporation } \\
\text { (mm) }\end{array}$ \\
\hline$H^{\prime}$ & -0.616 & $-0.911^{*}$ & 0.340 & $0.965^{* *}$ & $-0.813^{*}$ \\
\hline$D$ & -0.478 & $-0.953^{* *}$ & 0.179 & $0.917^{*}$ & $-0.872^{*}$ \\
\hline$J P$ & -0.272 & $0.801^{*}$ & 0.558 & 0.425 & $0.902^{*}$ \\
\hline
\end{tabular}

Table 2. Comparative analysis of grassland area between 2010 and $1980 \mathrm{~S}$ in DAMAOQI (thousand $\cdot \mathbf{h m}^{2}$ ).

\begin{tabular}{ccccccc}
\hline & \multicolumn{2}{c}{2010} & \multicolumn{2}{c}{ 1980s } & \multicolumn{2}{c}{$\begin{array}{c}\text { Comparative 2010 } \\
\text { with 1980s }\end{array}$} \\
\cline { 2 - 7 } \begin{tabular}{c} 
Grassland $\begin{array}{c}\text { The } \\
\text { types }\end{array}$ \\
\cline { 2 - 7 }
\end{tabular} & $\begin{array}{c}\text { The } \\
\text { total } \\
\text { area }\end{array}$ & $\begin{array}{c}\text { The } \\
\text { utilizing } \\
\text { area }\end{array}$ & $\begin{array}{c}\text { The total } \\
\text { area }\end{array}$ & $\begin{array}{c}\text { The } \\
\text { utilizing } \\
\text { area }\end{array}$ & $\begin{array}{c}\text { The total } \\
\text { area }\end{array}$ & $\begin{array}{c}\text { The } \\
\text { utilizing } \\
\text { area }\end{array}$ \\
\hline $\begin{array}{c}\text { Total } \\
\text { Typical }\end{array}$ & 1551.4 & 1396.3 & 1657.4 & 1508.0 & -106.0 & -111.7 \\
steppe & 397.7 & 358.0 & 482.0 & 431.8 & -84.2 & -73.9 \\
$\begin{array}{c}\text { desert } \\
\text { steppe }\end{array}$ & 852.2 & 767.0 & 875.0 & 801.0 & -22.8 & -34.1 \\
$\begin{array}{c}\text { steppe } \\
\text { desert }\end{array}$ & 212.8 & 191.5 & 221.9 & 208.3 & -9.1 & -16.8 \\
$\begin{array}{c}\text { lower-flat } \\
\text { mead-ow }\end{array}$ & 88.5 & 79.7 & 78.6 & 66.8 & 9.9 & 12.8 \\
\hline
\end{tabular}

tors. Compared to 1980 s, grassland area has dropped by 6.1 percent and mean productivity has reduced 14.7 percent. Grassland ecosystem has been suffered grave threats by those traditional methods of production and operating activities that mostly emphasis on the consumption and ignore the protection in animal husbandry. Human's living environments, health and safety are suffering unprecedented threats by the temperature increment, distribution of rain and extreme events of weather endless emergence. So the technology of soil and water conservation ecological rehabilitation must be Strengthen Urgently. Now, many successful methods were popularized and applied for preventing soil erosion and protecting grassland environment on the basis of scientific researches and experiment for years.

\subsection{The Technology of Comprehensive Improvement of Natural Pastures}

Enclose is one of most efficient and important technologies to realize the ecological rehabilitation in grassland. The main excellence is the rotational grazing; vegetation would be sufficiently and well utilized on desert steppe [11]. It has been applied in many regions to prevent degradation and better results have been obtained. Other effective methods include rain-fed artificial pasture, 
over-sowing etc.

\subsection{Utilization of Groundwater Resources and Water-Saving Irrigation Techniques}

Because of the arid and semi-arid region, the climate of most grassland shows the dryness and little rainfall, shortage of water resource effects plant growth, and then restricts the animal husbandry and herdsman's life. Many technology, equipments and methods are adopted for rational development of water resources, especially groundwater, such as water supply well, main pipe of irrigation system, hydrant, groundwater irrigation well, portable pipeline and motor-pumped well building etc. Constructing forage land would considered a successful combination of the water-saving irrigation technique, which would help to solve the problem of forage shortage and then accelerate the soil and water conservation on ecological fragile regions.

\subsection{Forage Land Construction with Water-Saving and High Irrigation}

Building forage land with water-saving, high-yield, highquality and efficient irrigation may increase the yield per unit area and grass quality greatly, which will solve the problem of supplying the forage to raise livestock. Combining with the full house feeding and semi house feeding, forage land creates conditions and convenience to carry out enclose, rest grazing and rotational grazing. The management mode may divides into two forms substantially based on the development of forage land construction, one is the large-scale and concentrated professional irrigation, and another is the family farms with small and scattered irrigation.

\subsection{Scientific Management of Grassland Utilization}

The most important of ecological rehabilitation is how to realize the grassland ecosystem sustainable development, regarded the scientific management as one of most efficient means. Carried on the policy of the household contract management in conjunction with forbidding grazing and delaying grazing to protect degraded grassland, enforce contracts with households and consolidate the protection and utilization of pasture resources.

\section{Acknowledgements}

This work was supported by the National Natural Sci- ence Foundation of China (No.40901136) and the science and technology Program of Inner Mongolia (No.20110533). We are grateful to Mr. Rong Hao, Mr. Liu Tiejun for their assistance in the field work.

\section{REFERENCES}

[1] J. Y. Zheng, X. M. Shao, Z. X. Hao, et al., "An Overview of Research on Climate Change in China during the Past 2000 Years," Geographical Research, Vol. 29, No. 9, 2010, pp. 1561-1569.

[2] Y. H. Ding, G. Y. Ren, G. Y. Shi, et al., "China's National Assessment Report on Climate Change (I): Climate change in China and Its Future Trend," Advances in Climate Change Research, Vol. 3, No. 1, 2007, pp. 16731719.

[3] Y. T. Yin, X. Y. Hou and X. J. Yun, "Advances in the Climate Change Influencing Grassland Ecosystems in Inner Mongolia," Prat Acultural Science, Vol. 28, No. 6, 2011, pp. 1132-1139.

[4] G. E. Feng, "Modern Ecology," Science Press, Beijing, 2002, pp. 45-47.

[5] R. A. Sherry, X. H. Zhou, S. L. Gu, et al., "Divergence of Reproductive Phenology under Climate Warming," PNAS, Vol. 104, No. 1, 2007, pp. 198-202. doi:10.1073/pnas.0605642104

[6] Z. F. Wu, Y. H. Jin and J. P. Liu, "Response of Vegetation distribution to global climate change in Northeast China," Scientia Geographica Sinica, Vol. 23S, No. 5, 2003, pp. 564-570.

[7] R. D. Alward, J. K. Detling and D. G. Milchunas, "Grassland Vegetation Changes and Nocturnal Global Warming," Science, Vol. 283, No. 5399, 1999, pp. 229-231. doi:10.1126/science.283.5399.229

[8] Y. H. Wang and G. H. Zhou, "Response of Leymus chinensis Grassland Vegetation on Inner Mongolia to Temperature Change," Acta Phytoeclolgica Sinica, Vol. 28, No. 4, 2004, pp. 507-514.

[9] S. Naeem, "Declining Biodiversity Can Alter the Performance of Ecosystems," Nature, Vol. 1368, No. 6473, 1994, pp. 734-737. doi: $10.1038 / 368734 \mathrm{a} 0$

[10] P. M. Vitousek, "Beyond Global Warming: Ecology and Global Change,” Ecology, Vol. 75, No. 7, 1994, pp. 18611876. doi:10.2307/1941591

[11] Q. F. Li, G. D. Han, T. G. Ao, et al., "Approach on Restoration Mechanism of Rotation Grazing System on Desert Steppe," Transaction of the CSAE, Vol. 19, No. 3, 2003, pp. 224-227. 